\title{
Unveiling the factors shaping the distribution of widely distributed alpine vertebrates, using multi-scale ecological niche modelling of the bat Plecotus macrobullaris
}

\author{
Antton Alberdi, Ostaizka Aizpurua, Joxerra Aihartza and Inazio Garin*
}

\begin{abstract}
Several alpine vertebrates share a distribution pattern that extends across the South-western Palearctic but is limited to the main mountain massifs. Although they are usually regarded as cold-adapted species, the range of many alpine vertebrates also includes relatively warm areas, suggesting that factors beyond climatic conditions may be driving their distribution. In this work we first recognize the species belonging to the mentioned biogeographic group and, based on the environmental niche analysis of Plecotus macrobullaris, we identify and characterize the environmental factors constraining their ranges. Distribution overlap analysis of 504 European vertebrates was done using the Sorensen Similarity Index, and we identified four birds and one mammal that share the distribution with P. macrobullaris. We generated 135 environmental niche models including different variable combinations and regularization values for $P$. macrobullaris at two different scales and resolutions. After selecting the best models, we observed that topographic variables outperformed climatic predictors, and the abruptness of the landscape showed better predictive ability than elevation. The best explanatory climatic variable was mean summer temperature, which showed that $P$. macrobullaris is able to cope with mean temperature ranges spanning up to $16^{\circ} \mathrm{C}$. The models showed that the distribution of $P$. macrobullaris is mainly shaped by topographic factors that provide rock-abundant and open-space habitats rather than climatic determinants, and that the species is not a cold-adapted, but rather a cold-tolerant eurithermic organism. P. macrobullaris shares its distribution pattern as well as several ecological features with five other alpine vertebrates, suggesting that the conclusions obtained from this study might be extensible to them. We concluded that rock-dwelling and open-space foraging vertebrates with broad temperature tolerance are the best candidates to show wide alpine distribution in the Western Palearctic.
\end{abstract}

Keywords: Alpine distribution, Alpine long-eared bat, Biogeography, Chiroptera, Distribution, Modelling, Mountain long-eared bat, Zoogeography

\section{Introduction}

Studying the causes shaping distribution patterns is one of the major tasks in biogeography [1]. Many organisms exhibit similar distributions that despite their current ranges could be the result of different historical, ecological and physiological processes. Identifying the common factors constraining their range is key to understanding these geographic analogies. The joint characteristic attribute of

\footnotetext{
* Correspondence: inazio.garin@ehu.es
Department of Zoology and Animal Cell Biology, Faculty of Science and
Technology, University of The Basque Country UPV/EHU, Sarriena auzoa s/n,

* Correspondence: inazio.garin@ehu.es
Department of Zoology and Animal Cell Biology, Faculty of Science and
Technology, University of The Basque Country UPV/EHU, Sarriena auzoa s/n

* Correspondence: inazio.garin@ehu.es
Department of Zoology and Animal Cell Biology, Faculty of Science and
Technology, University of The Basque Country UPV/EHU, Sarriena auzoa s/n, 48940 Leioa, The Basque Country
}

(c) 2014 Alberdi et al.; licensee BioMed Central Ltd. This is an Open Access article distributed under the terms of the Creative Commons Attribution License (http://creativecommons.org/licenses/by/4.0), which permits unrestricted use, distribution, and reproduction in any medium, provided the original work is properly credited. The Creative Commons Public Domain Dedication waiver (http://creativecommons.org/publicdomain/zero/1.0/) applies to the data made available in this article, unless otherwise stated.

alpine species is the geographic restriction to high mountain environments, which were covered with ice-sheets during long periods in the Pleistocene [2]. The study of the biogeographic patterns of Eurasian alpine species has mainly targeted plants and invertebrates [3-6] that due to either low or no mobility $[7,8]$ are largely conditioned by edaphic and climatic factors [9]. Most vertebrates, however, are unique in their higher mobility, and due to their distinct ecological and evolutionary traits, the biogeographic patterns of vertebrates are likely to differ from those of plants and invertebrates. BioMed Central 
The distribution patterns of high mountain vertebrates in the Western Palearctic vary considerably. Endemics restricted to one or few mountain systems are common mainly among vertebrates with low mobility $[10,11]$. Most volant species however show wider distributions. Many of them are ubiquitous and can be commonly found in other habitats in addition to alpine environments [12], and few arctic-alpine species show broad boreal distributions with isolated relict populations in alpine areas at lower latitudes [13]. Finally, there is a group of species sharing a broad geographic distribution restricted to Southern Palearctic mountain systems, hereafter referred to as palealpine species, whose distribution pattern has so far received little attention. The distribution of a single bat species, the alpine long-eared bat (Plecotus macrobullaris) is also known to fit this biogeographic pattern [14]. P. macrobullaris is a recently described species [15-17] known to forage in alpine meadows [18] and roost mainly in rock crevices and talus slopes [19]. Unlike other bat species in the Western Palearctic [20], this species has breeding populations in the subalpine and alpine belts of mountain systems in the South-western Palearctic [14].

The factors explaining why palealpine vertebrates like $P$. macrobullaris are restricted to mountain environments, yet absent from the rest of the region, have so far not been addressed. Although species inhabiting alpine environments are commonly regarded as cold-adapted species [21], this relationship is not always accurate. Whilst species with arctic-alpine distributions are physiologically restricted to cold conditions and remain active in the alpine belt during the winter [13], this is not necessarily the case for all alpine species [22]. In fact, the current distribution of many palealpine species also includes relatively warm areas in South-eastern Europe and the Middle East [23], suggesting that factors beyond climatic conditions likely dictate the distribution of these species.

Identifying the factors constraining geographic ranges requires using the correct resolution and extent [24] because the distribution of species is shaped by processes acting at different scales [25-27]. Climatic factors mainly drive the continental scale distribution due to the physiological limits of species [28]. Ecological features, instead, usually act more locally and require finer resolution [29,30]. Additionally, the effect of topographic factors such as slope or aspect also depends on scale [31]. Hence, a multiple resolution and extent approach allows the input of variables in the correct scale in which they act, providing more representative outputs of the environmental factors limiting the distribution of species [32].

In this study we test whether climatic variables or habitat and topographic factors are the main drivers of the distribution of palealpine vertebrates, so that the main factors constraining their distribution are identified. First, we identify the vertebrate species that exhibit palealpine distribution analysing range similarities. And secondly, in order to understand why palealpine species are closely linked to mountain environments, we apply our modelling approach at two spatial scales using $P$. macrobullaris as model species. At the broad-scale, across the Western Palearctic, we use coarse-grain presence records of the species for continental-level modelling, while at the fine-scale, around the Pyrenees, we use precise roosting records and finer spatial resolution to understand the factors shaping the local distribution.

\section{Results}

The Sørensen Similarity Index (SSI) value between the distribution area we generated based on updated distribution information of P. macrobullaris [14] and the area available at IUCN Red List was 0.66. Thus, that was the error-factor we used for calculating the corrected SSI (cSSI) values of the other species, since we consider it more adjusted to the actual distribution similarity between species (Figure 1). The distribution overlap analysis showed that four birds and a single mammal share the geographic distribution with $P$. macrobullaris, namely the birds Montifringilla nivalis, Pyrrhocorax graculus, Tichodroma muraria, Prunella collaris and the vole Chionomys nivalis (Figure 1). All these species showed cSSI values above 0.6, while the average cSSI values for birds and mammals were $0.15 \pm 0.15$ and $0.12 \pm 0.14$ respectively. The average cSSI value for bats was $0.18 \pm 0.12$.

\section{Broad-scale distribution modelling}

Analysed evaluators showed that the model with the best predictive ability was the one including one topographic (ABR), five climatic (B4, B10, B12, B15 and B17) and one habitat-related (LAND) variables, generated with a regularization multiplayer of $\beta=1$ (Table 1 , Additional file 1 : Table S1). The predictive value of abruptness outperformed elevation in all the analysed cases. The Spearman correlation values $(\rho)$ between elevation and mean summer temperature were -0.97 in the regional scale and -0.43 in the continental scale.

Areas with suitability values below 0.2886 (max SSS) were considered unsuitable, and $89.4 \%$ of the total known distribution records were located in suitable cells. The best model showed suitable areas in the main mountain ranges of the Southern Palearctic, as well as some areas of Northern Europe (Figure 2). All metrics indicated that abruptness was the variable with the best explanatory power (Table 2, Additional file 2: Figure S2). The second most important variable, based on all analysed metrics, was the mean temperature of the warmest quarter (B10), and the remaining climatic and habitat-related variables obtained lower values in all the evaluated metrics. The response curve of the best explanatory variable 


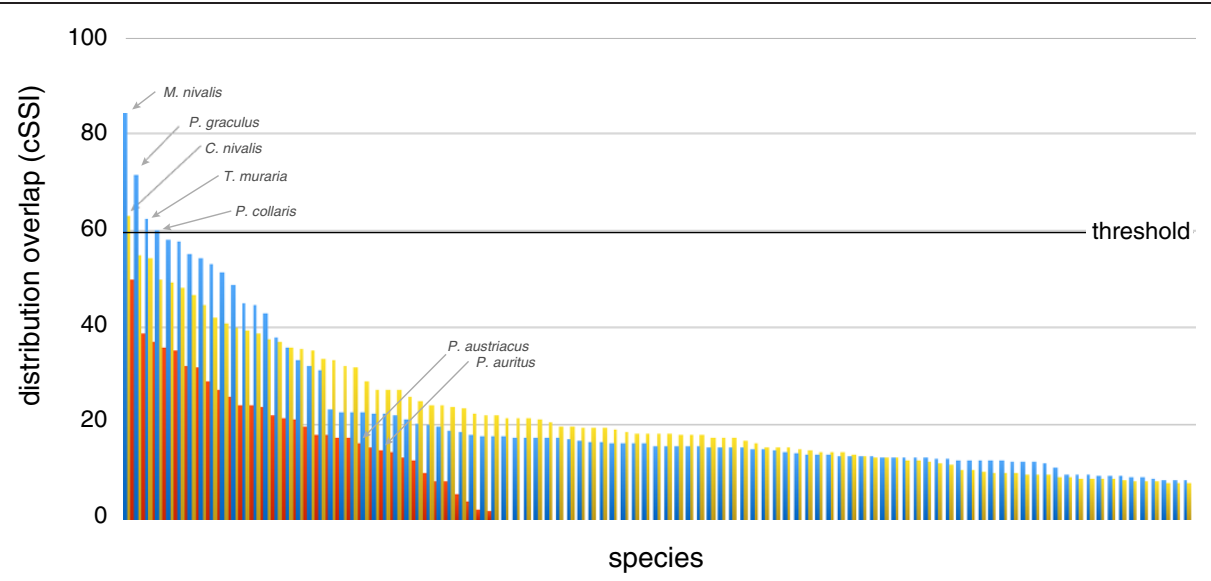

Figure 1 Geographic overlap between the distribution of $P$. macrobullaris and the distributions of analysed European vertebrates. Blue bars indicate birds, yellow bars indicate non-chiropteran mammals and red bars indicate bats. The names of the five species with the highest distribution resemblance, and the positions of $P$. auritus and $P$. austriacus are shown. Note that the species with cSSI values equal to 0 (distributions not-overlapped) are not shown and the list of species of birds and non-chiropteran mammals is limited to 100 species.

Table 1 Composition, evaluation scores (AUCtest, AICc and MPA) and variable contribution ranks of the best models

\begin{tabular}{|c|c|c|c|c|c|c|}
\hline \multicolumn{7}{|l|}{ Broad-scale modelling } \\
\hline Type & Model & $\beta$ & $A \cup C_{\text {test }}$ & AICc & MPA & Variable contribution rank \\
\hline \multirow[t]{2}{*}{ Climatic } & $\mathrm{B} 8, \mathrm{~B} 10, \mathrm{~B} 12, \mathrm{~B} 17$ & 1 & 0.881 & 2688.1285 & 0.3383 & $\mathrm{~B} 10(45.3)>\mathrm{B} 12>\mathrm{B} 8>\mathrm{B} 17$ \\
\hline & $\mathrm{B} 4, \mathrm{~B} 10, \mathrm{~B} 12, \mathrm{~B} 15, \mathrm{~B} 17$ & 1 & 0.880 & 2619.7250 & 0.2972 & $\mathrm{~B} 10(43.7)>\mathrm{B} 12>\mathrm{B} 17>\mathrm{B} 15>\mathrm{B} 4$ \\
\hline \multirow[t]{2}{*}{ Topographic } & ABR, ELEV & 1 & 0.873 & 2434.7099 & 0.365 & ABR (84.4) > ELEV \\
\hline & ABR, ELEV & 2 & 0.866 & 2478.7364 & 0.343 & ABR (86.1) > ELEV \\
\hline \multirow[t]{2}{*}{ Climatic + Topographic } & $\mathrm{B} 4, \mathrm{~B} 8, \mathrm{~B} 10, \mathrm{~B} 12, \mathrm{~B} 15, \mathrm{~B} 17, \mathrm{ELEV}, \mathrm{ABR}$ & 1 & 0.905 & 2542.8793 & 0.201 & $\begin{array}{l}\mathrm{ABR}(71.7)>\mathrm{ELEV}>\mathrm{B} 10>\mathrm{B} 17>\mathrm{B} 12>\mathrm{B} 15> \\
\mathrm{B} 4>\mathrm{B} 8\end{array}$ \\
\hline & $\mathrm{B} 4, \mathrm{~B} 8, \mathrm{~B} 10, \mathrm{~B} 12, \mathrm{~B} 15, \mathrm{~B} 17, \mathrm{ABR}$ & 2 & 0.911 & 2409.3266 & 0.237 & $\mathrm{ABR}(79.9)>\mathrm{B} 10>\mathrm{B} 12>\mathrm{B} 15>\mathrm{B} 17>\mathrm{B} 4>\mathrm{B} 8$ \\
\hline \multirow[t]{2}{*}{ Climatic + Habitat } & B4, B8, B10, B12, B15, B17, LAND & 1 & 0.899 & 2426.4305 & 0.271 & $\mathrm{~B} 10(32.7)>\mathrm{B} 12>\mathrm{LAND}>\mathrm{B} 8>\mathrm{B} 17>\mathrm{B} 15>\mathrm{B} 4$ \\
\hline & B4, B10, B12, B15, B17, LAND & 1 & 0.889 & 2472.1983 & 0.237 & $\mathrm{~B} 10(37.0)>\mathrm{B} 12>$ LAND $>\mathrm{B} 17>\mathrm{B} 15>\mathrm{B} 4$ \\
\hline \multirow[t]{2}{*}{ Topographic + Habitat } & ELEV, ABR, LAND & 1 & 0.873 & 2333.0673 & 0.321 & ABR (86.7) > ELEV > LAND \\
\hline & ABR, LAND & 2 & 0.876 & 2379.0112 & 0.321 & ABR (96.6) > LAND \\
\hline \multirow[t]{2}{*}{$\begin{array}{l}\text { Climatic + Topographic + } \\
\text { Habitat }\end{array}$} & $\mathrm{B} 4, \mathrm{~B} 8, \mathrm{~B} 10, \mathrm{~B} 12, \mathrm{~B} 15, \mathrm{~B} 17, \mathrm{ABR}$, LAND & 1 & 0.903 & 2334.3659 & 0.178 & $\begin{array}{l}\mathrm{ABR}(70.6)>\mathrm{B} 10>\mathrm{B} 17>\mathrm{LAND}>\mathrm{B} 15>\mathrm{B} 12> \\
\mathrm{B} 8>\mathrm{B} 4\end{array}$ \\
\hline & B4, B10, B12, B15, B17, ABR, LAND & 1 & 0.912 & 2330.3513 & 0.208 & $\begin{array}{l}\mathrm{ABR}(75.1)>\mathrm{B} 10>\mathrm{B} 1012>\mathrm{B} 17>\mathrm{B} 15> \\
\mathrm{LAND}>\mathrm{B} 4\end{array}$ \\
\hline \multicolumn{7}{|l|}{ Fine-scale modelling } \\
\hline Type & Model & $\beta$ & $A U C_{\text {test }}$ & AICc & MPA & Variable contribution rank \\
\hline \multirow[t]{2}{*}{ Topographic } & ELEV, SLOP, ORI & 1 & 0.9294 & 1087.2041 & 0.1381 & ELEV (56.3) > SLO > ORI \\
\hline & ELEV, SLOP & 1 & 0.9298 & 1108.6065 & 0.1574 & ELEV (54.9) > SLO \\
\hline \multirow[t]{2}{*}{ Habitat } & DIS-URBAN, DIS-FOREST, DIS-ROCK & 1 & 0.8968 & 1161.1387 & 0.2449 & dis-rock $(74.3)>$ dis-urban $>$ dis-forest \\
\hline & DIS-URBAN, DIS-ROCK & 1 & 0.8943 & 1321.0146 & 0.2471 & dis-rock (89.3) > dis-urban \\
\hline \multirow[t]{2}{*}{ Topographic + Habitat } & $\begin{array}{l}\text { ELEV, SLOP, ORI, DIS-URBAN, } \\
\text { DIS-FOREST, DIS-ROCK }\end{array}$ & 1 & 0.9429 & 1289.9253 & 0.0871 & $\begin{array}{l}\text { dis-rock }(32.0)>\text { SLO }>\text { ELEV }>\text { dis-urban }> \\
\text { dis-forest }>\text { ORI }\end{array}$ \\
\hline & ELEV, SLOP, DIS-URBAN, DIS-ROCK & 1 & 0.9560 & 1199.8611 & 0.1026 & dis-rock (34.4) > SLO > ELEV > dis-urban \\
\hline
\end{tabular}

Only the two models that obtained the best values in each variable-type combination are shown. The rest of the models can be found in Tables S1 and S2 in the Additional file 1. The contribution percentage of the best-ranked variable in each model is indicated in brackets. The selected models are marked in bold. 


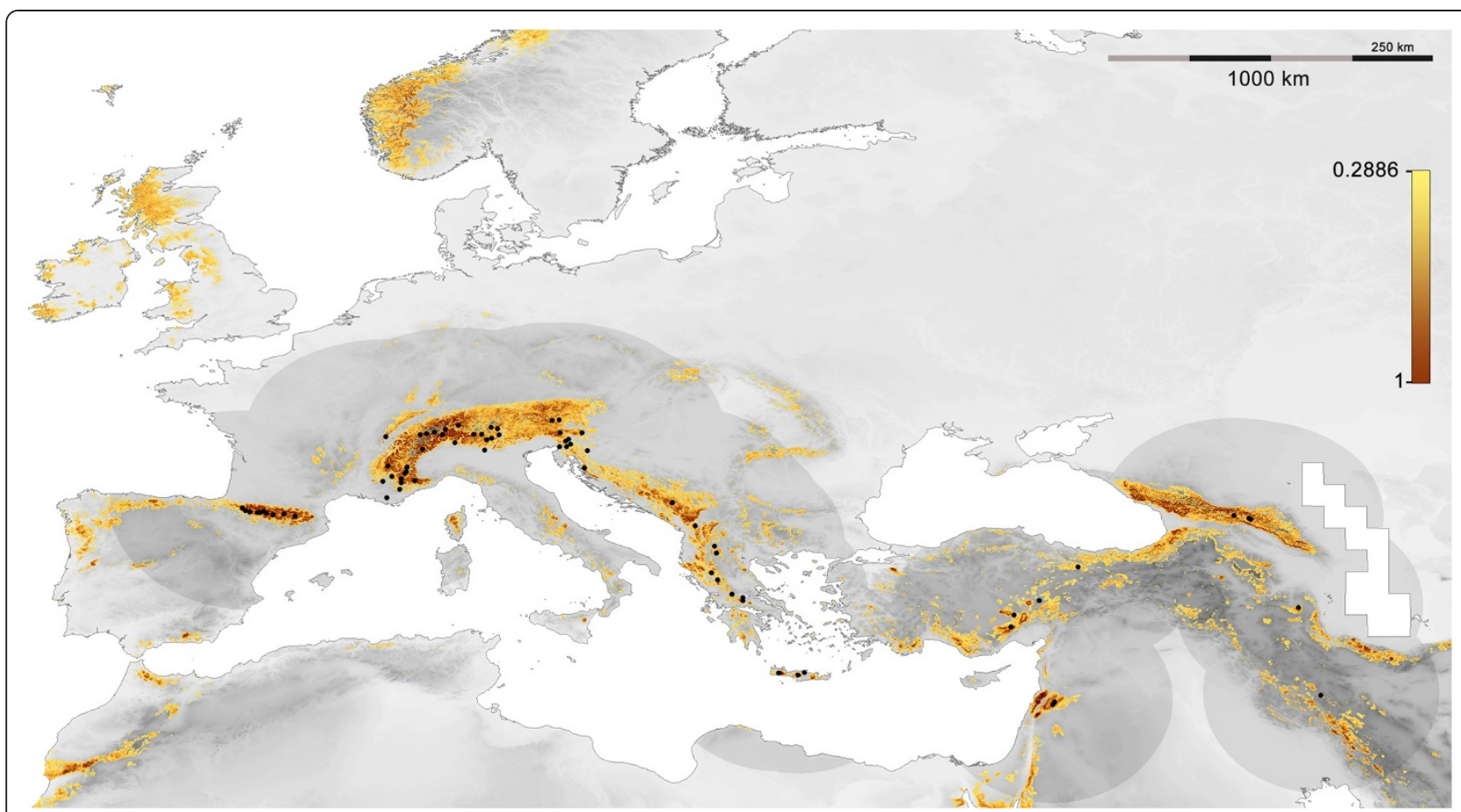

Figure 2 Distribution model for $\boldsymbol{P}$. macrobullaris, presented on a greyscale elevation map. Only suitable areas (SV >0.2886) are shown in a colour gradient from light yellow (low suitability) to brown (high suitability). Presence location records used for modelling are represented by black dots and the darkened region is the area used for calibrating the model.

showed that suitability increased with abruptness, starting with zero probability of presence in flat regions (Figure 3A). The most suitable mean temperature of the warmest quarter was $14^{\circ} \mathrm{C}$, but suitable values ranged from 6 to $22^{\circ} \mathrm{C}$ (Figure 3B).
Fine-scale roosting habitat suitability modelling

The best model was built using two habitat (distance to rocky and urban areas) and two topographic variables (elevation and slope) (Table 1, Additional file 1: Table S2). The ENM showed good predictive ability (AUC $=0.956$ ).

Table 2 Different metrics on the contribution of variables to the best models

\begin{tabular}{|c|c|c|c|c|}
\hline Variable & Relative contribution & Permutation importance & $\begin{array}{l}\text { Jackknife training gain } \\
\text { with only variable }\end{array}$ & $\begin{array}{l}\text { Jackknife training gain } \\
\text { without this variable }\end{array}$ \\
\hline \multicolumn{5}{|c|}{ Broad-scale modeling } \\
\hline ABR & 75.10 & 45.45 & 1.05 & 1.05 \\
\hline B10 & 9.01 & 28.17 & 0.64 & 1.25 \\
\hline B12 & 3.86 & 7.34 & 0.59 & 1.34 \\
\hline B17 & 4.63 & 6.45 & 0.41 & 1.34 \\
\hline B15 & 2.34 & 2.28 & 0.09 & 1.34 \\
\hline LAND & 3.70 & 1.57 & 0.20 & 1.33 \\
\hline B4 & 1.33 & 8.71 & 0.11 & 1.34 \\
\hline \multicolumn{5}{|c|}{ Fine-scale modeling } \\
\hline DIS-ROCK & 34.36 & 42.86 & 0.97 & 1.71 \\
\hline SLOPE & 31.68 & 14.36 & 1.16 & 1.53 \\
\hline ELEV & 25.50 & 28.49 & 1.02 & 1.68 \\
\hline DIS-URBAN & 8.44 & 14.27 & 0.30 & 1.73 \\
\hline
\end{tabular}

All values are averages of the 50 replicates of the best models. The relative contribution is obtained from the increase of the regularized gain when each variable is added to the model. The permutation importance is obtained by randomly permuting the values of that variable among the training points and measuring the decrease in training AUC produced by the permutation. The Jackknife training gain with only variable is the training gain that the model achieves when using only that variable, and the Jackknife training gain without this variable is the training gain that the model achieves when using the rest of variables except that one. Consequently, in the first three metrics larger values indicate higher contribution of variables to the model, while in the last one, the lower values indicate greater importance of variables to the model. 

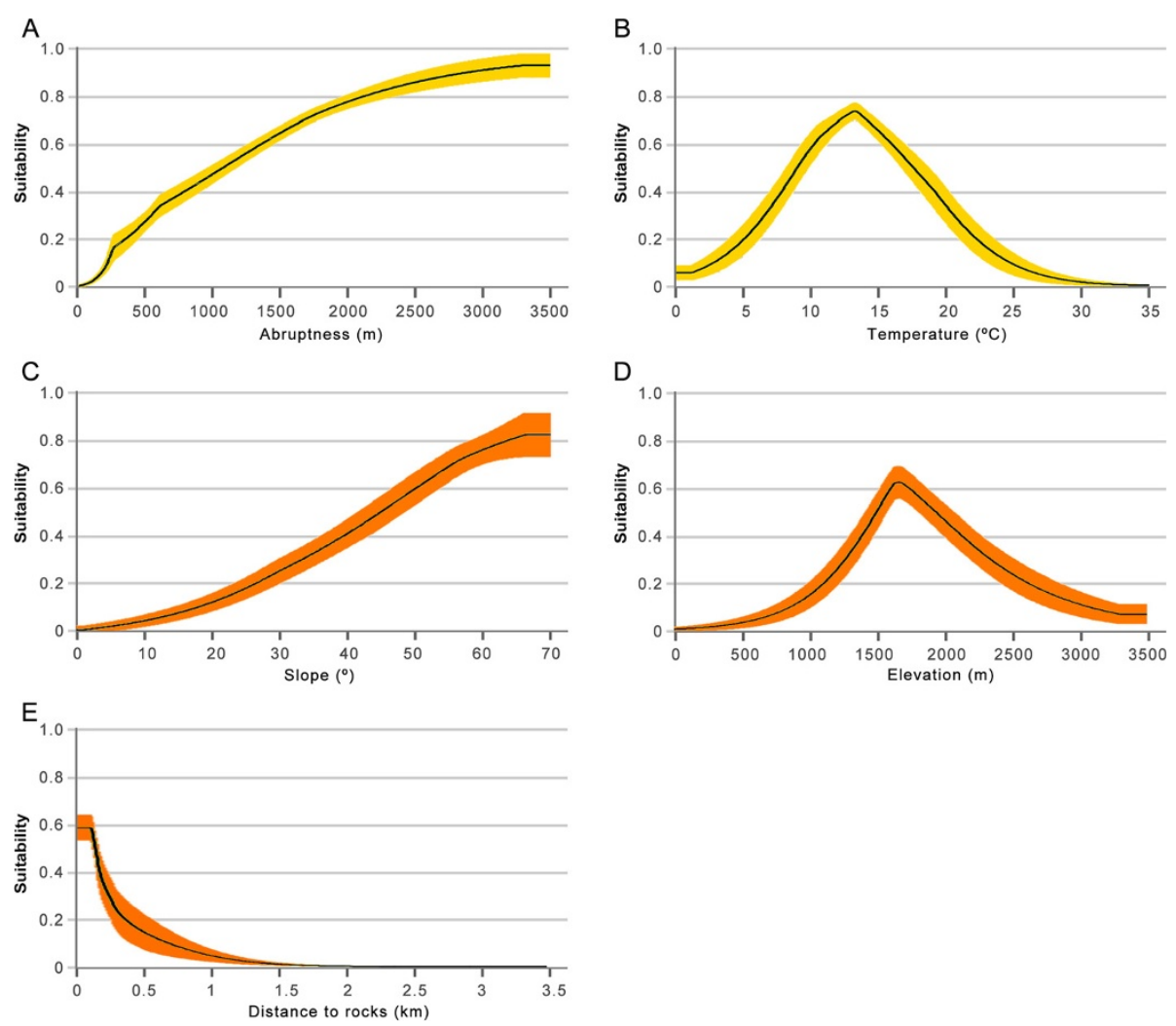

Figure 3 Response curves of variables with the highest predictive ability. (A) Abruptness and (B) mean temperature of the warmest quarter, as estimated by the broad-scale modelling; (C) slope, (D) elevation and (E) distance to rocks (DIS-ROCK), as estimated by the fine-scale modelling.

The three main factors shaping roosting habitat suitability for $P$. macrobullaris were the distance to rock areas (DIS-ROCK), slope and elevation. DIS-ROCK was the variable with the highest relative contribution to the best model, and Jackknife tests stressed the importance of slope and elevation (Table 2, Additional file 2: Figure S3). The closer the rocks and higher the slope the greater the probability of finding suitable roosting sites (Figure $3 \mathrm{C}$ and $\mathrm{E}$ ). The response curve for elevation showed suitable areas for roosting in an elevation range from 1300 to $2400 \mathrm{~m}$, with maximum values between 1500 and $2000 \mathrm{~m}$ (Figure 3D).

\section{Discussion}

The distribution overlap analysis showed that P. macrobullaris shares its distribution pattern with five other vertebrates: the birds Montifringilla nivalis, Pyrrhocorax graculus, Tichodroma muraria and Prunella collaris, as well as the rodent Chionomys nivalis. Despite slight differences can be observed between the ranges of the mentioned species, they are all widely distributed but restricted to mountain environments (Figure 4). Therefore, the conclusions obtained from the ENM of P. macrobullaris are probably extensible to all of them.
Additionally, as it is discussed below, all species exhibit similar ecological features. A handful of other birds, such as Anthus spinoletta (cSSI $=0.58$ ), Pyrrhocorax pyrrhocorax (0.57) or Turdus torquatus (0.53) were also linked to mountain environments, although their geographical distribution extends beyond the main mountain chains. The distribution range of the rest of analysed vertebrates showed lower resemblance with palealpine species (Figure 1).

The generated broad-scale model predicted that suitable areas for P. macrobullaris are found in almost all mountain ranges in the Western Palearctic, including some ranges where the species has not being hitherto reported. The species might be present in the Atlas Mts. in Morocco as well as in several mountain chains in the Iberian and Italian Peninsulas, as occurs with some other palealpine species (Figure 4). Two of the palealpine birds inhabit the Atlas while the Cantabrian Mts. and the Apennines host all the mentioned species. On the other hand, the presence of the species in the suitable mountain ranges of Scotland and Scandinavia seems implausible. Both ranges were covered by ice caps during Pleistocene glaciations [33], and the large unsuitable flatland separating them from the southern mountain 


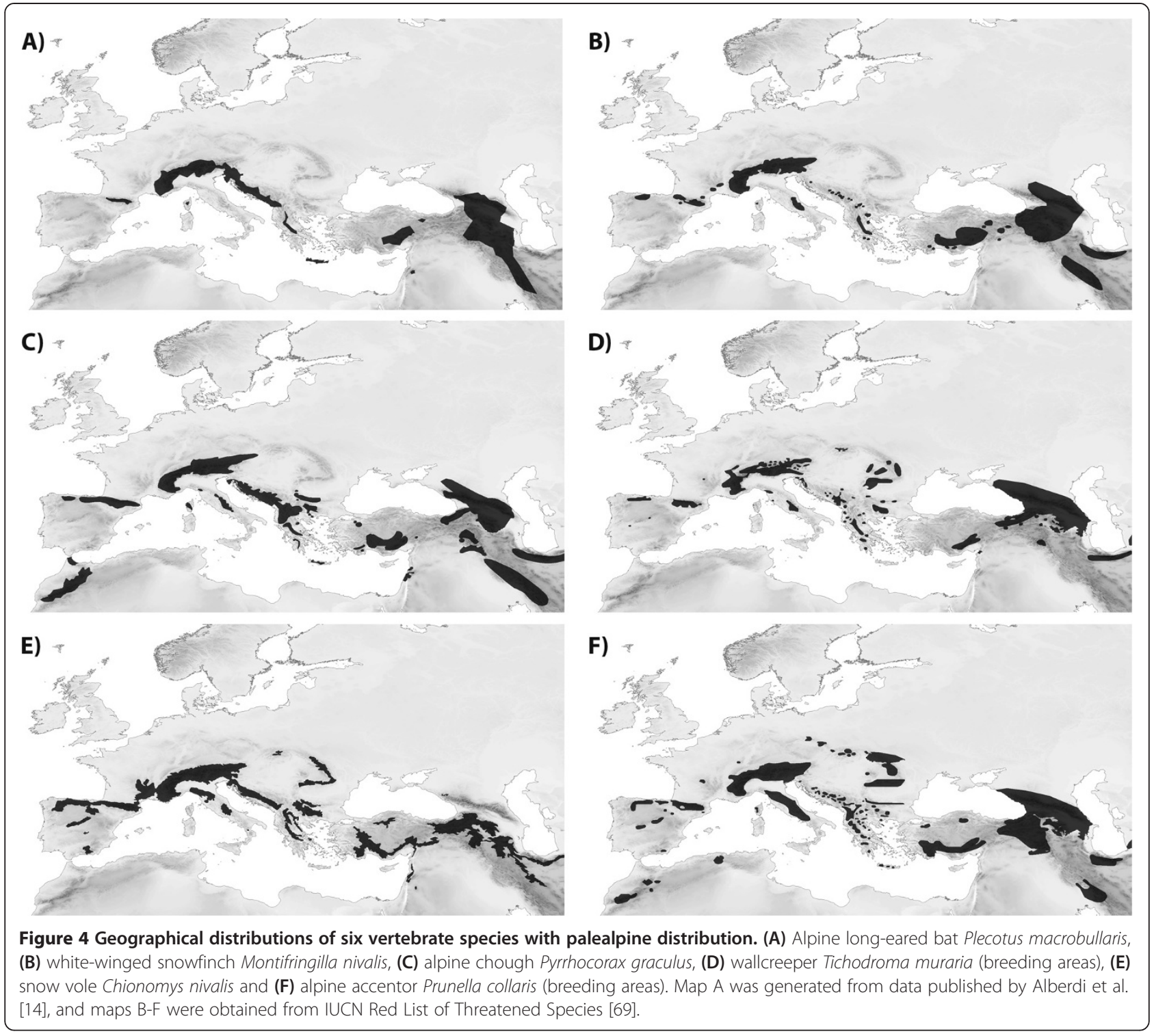

ranges could have prevented their postglacial colonisation by palealpine species. Additionally, harder climatic conditions in winter than in Southern Europe might be another reason that hampers colonisation. This view is supported by the distribution of other palealpine species, which are absent from both Scotland and Scandinavia despite the relatively high mobility of most of them (Figure 4).

Our results differ from the previously published ecological niche model of $P$. macrobullaris in Switzerland [34], which predicted a distribution restricted to lower elevations than what our model did for the Alps. Nevertheless, both research are hardly comparable as they only used localities of colonies detected in buildings at valley bottoms for generating their ENM, which might led to a biased model of the distribution of $P$. macrobullaris, since the species also uses natural roosting resources [19], and it has been also reported above the treeline in the Alps [14].

\section{The role of topographic variables}

Our models identified the abruptness of the landscape as the main constraint acting on the broad-scale distribution of $P$. macrobullaris, over-performing elevation in all cases. Unlike other variables linked to the elevation gradient (abruptness and slope), the effect of elevation itself was not consistent across spatial scales. Even though elevation is broadly used as a predictor in species distribution modelling [35], it does not directly affect the distribution of species on its own, but acts as a surrogate for several other habitat and climatic factors [36]. Thus, elevation may be a good predictor in regional-scale 
modelling [37], but its predictive ability decreases when moving from the regional to the continental scale, because it loses its ecological relevance (in the case of summer mean temperature, correlation value with elevation drops from $\rho=-0.97$ in the Pyrenees to $\rho=-0.43$ across the whole Palearctic). The great variation in the suitable elevation range between massifs (Figure 5) supports this statement.

Abruptness likely acts as a surrogate of several ecological variables. One of them is high rock availability, an important resource for palealpine species. In fact, the finescale modelling disclosed the importance of the proximity of rocky environments and the steepness of the terrain, surfacing the significance of rock walls and their debris. The five vertebrates identified as palealpine species depend on rocks for sheltering [38-40]. Cliffs and talus slopes are also a key roosting resource for $P$. macrobullaris [19], even though it also uses buildings for sheltering $[34,41,42]$. The relative area of rock outcrops is extensive at high mountain environments, favouring roost availability for saxicolous species. This behaviour probably allowed palealpine species to expand their ranges throughout the narrow and steep mountain massifs in the Western Palearctic. For instance, most snowfinches (genera Montifringilla, Pyrgilauda and Onychostruthus) roost on the ground and are behaviourally adapted to living in steppes [38], but only the saxicolous $M$. nivalis has expanded its distribution towards the European mountain massifs.

Another characteristic shared by all palealpine species is their preference for foraging in open areas, mainly in habitats with short grassy vegetation and rocks [18,43-45]. Climatic factors hamper the development of wood patches in alpine areas, providing suitable grounds for open-space foragers. Steep environments at lower elevation can also provide similar open habitats aided by the outcrop of bedrock and the decrease in soil thickness.

Finally, the high elevation range of mountain areas allows species to perform short-distance altitudinal migrations. Boreal species cannot avoid adverse atmospheric conditions by performing short migrations, and instead need to be physiologically adapted to extreme cold temperatures. In contrast, palealpine species tend to commute to lower elevations when conditions become harsher [39,46,47], and therefore physiological adaptations to the extreme cold may not be a compulsory requirement for them. Despite altitudinal migration have been documented in bats [48], such a behaviour has not been studied in P. macrobullaris
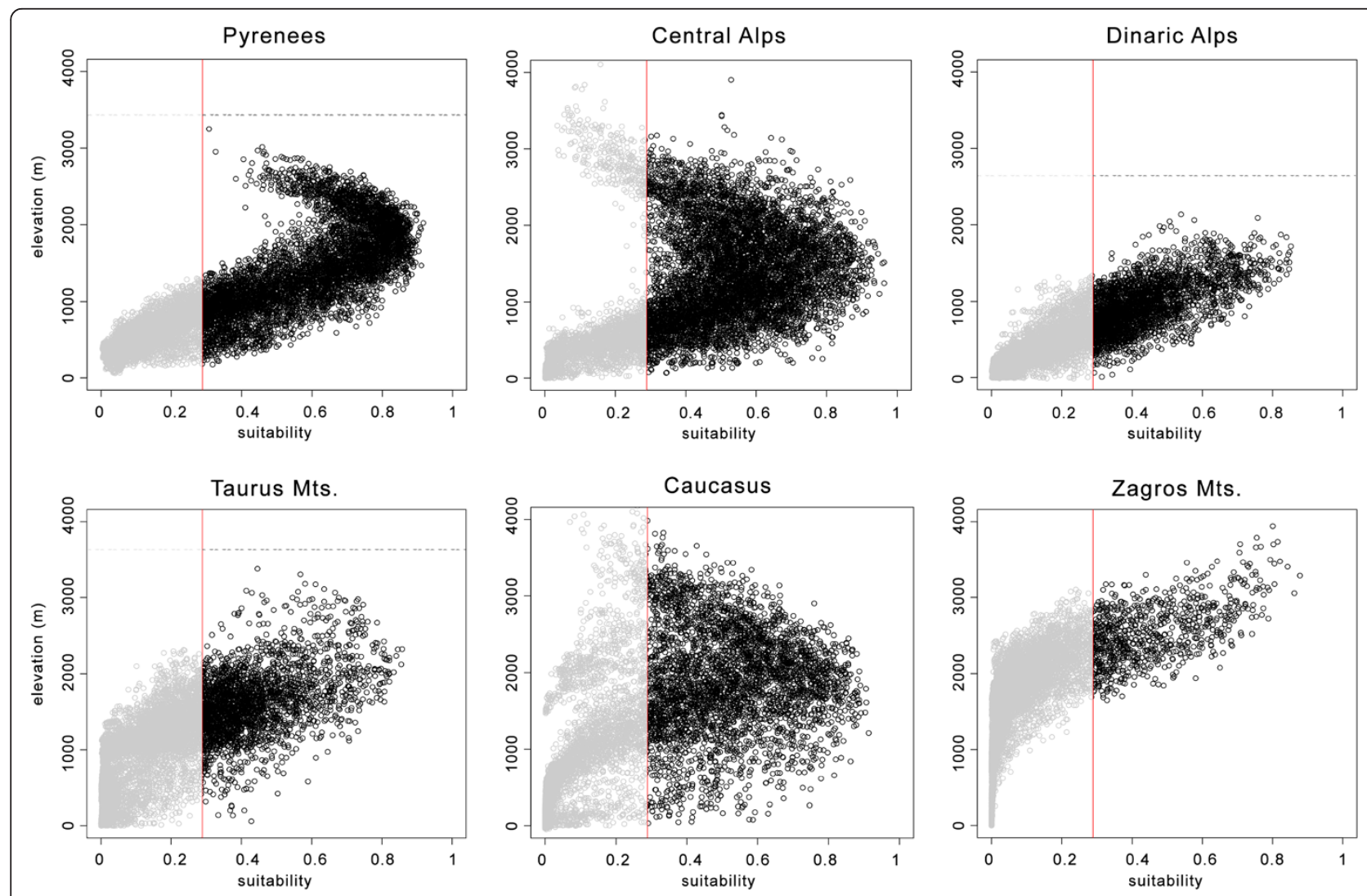

Figure $\mathbf{5}$ Relationship between suitability and elevation in six mountain massifs. Vertical red lines indicate the lower suitability boundary. Horizontal dotted lines indicate the maximum elevation of the mountain range. 
so far. Nevertheless, it seems implausible bats could remain the whole year in alpine environments, and ecological features as well as comparative biogeography suggest that $P$. macrobullaris may actually perform seasonal altitudinal migrations [18].

\section{The role of climatic variables}

Despite the lower contribution of climatic variables compared to topographic factors, the former also influenced the broad-scale model. Temperature mainly encompasses the altitudinal domains of the species' distribution. Different climatic patterns along the elevation gradients of each mountain range (with differences of up to $13^{\circ} \mathrm{C}$ in mean summer temperature at the same elevation; Additional file 2: Figure S4) produced contrasting suitability-elevation relationships between mountain chains across the predicted range of $P$. macrobullaris (Figure 5). For instance, suitable areas in the Zagros Mountains (Iran) were restricted to areas above $1100 \mathrm{~m}$, whereas near-sea-level areas of the Alps and the Dinaric Alps were considered suitable. This fact explains the poor predictive ability of elevation in the continental scale models. The fine-scale model also reflected the limiting effect of temperature in the Pyrenees, since no areas above $2600 \mathrm{~m}$ were considered suitable despite containing abundant steep areas.

Broad-scale modelling showed that $P$. macrobullaris, and by extension palealpine species, are able to cope with mean summer temperatures that span from 6 to $22^{\circ} \mathrm{C}$ (Figure 3B), revealing their eurithermic nature. Even though palealpine vertebrates were previously considered as cold-adapted species [21], their distribution is not restricted to cold environments, suggesting they are cold-tolerant rather than cold-adapted. Climatic models have predicted that alpine species like $P$. graculus and $M$. nivalis might extend their distribution to high latitude areas due to climate change [21]. Even though those areas might become climatically suitable for alpine species, our results suggest that such a scenario is highly improvable. We show that topography and its correlating ecological factors are shaping mostly the distribution of such species, and thus, the large unsuitable flatland between boreal areas and Southern European mountain ranges would hamper putative colonisation events. The wide thermal tolerance likely facilitated the colonisation of most of the mountain massifs in the Central and Southern Palearctic. Conversely, the southern isolated populations of an arctic-alpine vertebrate such as the rock ptarmigan (Lagopus muta) are limited to mountain ranges that hold extensive areas with summer mean temperatures below $10^{\circ} \mathrm{C}$, i.e. the Pyrenees and the Alps in Europe [49].

\section{The human factor}

In addition to topographic and climatic factors, human activities probably affected the distribution of palealpine vertebrates. Similar to other palealpine species [43,50,51], P. macrobullaris is also an open-space forager [18]. The natural treeline in the Pyrenees is expected to be around 2000-2200 m; however, historical landscape management for pasture has lowered the upper forest limit to around $1500 \mathrm{~m}$ [52]. It is noteworthy that the most suitable elevation range predicted by both models for the Pyrenees coincides with this modified belt $(1500-2000 \mathrm{~m})$, which suggests that it may offer the best ecological conditions for $P$. macrobullaris and other palealpine vertebrates in terms of greater food abundance and diversity [53] and milder climatic conditions than at higher elevations [54]. Hence, future changes in landscape management due to pastoral abandonment will likely affect the foraging ecology of P. macrobullaris [18] and other alpine vertebrates [44].

\section{Biotic interactions}

The importance of biotic interactions in the distribution of species is a largely recognised phenomenon [55]. Processes like competitive exclusion [56] or predator-prey relationships [57] can affect the distribution of species, in addition to climatic and habitat-related factors. Accordingly, Rutishauser et al. [34] reported that the mostly allopatric distribution of $P$. macrobullaris and $P$. austriacus in Switzerland might be the result of competitive exclusion. In fact, both species share ecological traits [18,58,59]. However, under this scenario sympatric populations would be the exception rather than the rule and the niche of P. macrobullaris would expand where it is released from interspecific competition. Neither one nor the other seems to occur. There are broad areas where both species are found in sympatry, such as the Pyrenees (own data), the French Prealps [60] and the Dinaric Alps [61], and the ecological niche of $P$. macrobullaris as well as its link to mountain environments is kept beyond the range of $P$. austriacus, e.g. the eastern part of the distribution of $P$. macrobullaris. Competitive exclusion might occur in some specific areas like Switzerland, or across the altitudinal gradient in precise contact zones [62]. We do not discard that competitive exclusion shows up where resources are limiting, but in our opinion there are no signs indicating a general effect on the ecological niche and continental-level distribution of $P$. macrobullaris.

\section{The environmental niche of palealpine species}

Our results show that climatic factors are not the main drivers of the distribution of palealpine vertebrates. Generally, the broad-scale geographic distribution of species tend to be limited by climatic variables [28], while nonclimatic factors usually shape their distribution at the regional or local level [63]. However, our models show that in the case of palealpine species topographic factors act at a broader scale. Unlike arctic-alpine organisms, palealpine species are able to thrive in relatively warm as well as cold 
temperatures, and this eurithermicity is responsible for the limited ability of climatic variables to predict their distribution at the broad-scale.

Although palealpine species share the same biogeographic pattern driven by topographic factors, they are expected to show differential responses to climatic conditions. Variations in behaviour as well as geographical and altitudinal distribution suggest that some species cope better with cold than others, e.g. the white-winged snowfinch compared to the wallcreeper [23]. Differences in thermal tolerance between groups of organisms are also expected to occur due to differences in their ecology, reproduction and physiology. Major differences between birds and bats probably stem from their distinct circadian rhythm, thermoregulation abilities and reproductive systems. Birds are diurnal, homeothermic and oviparous animals [64], while bats are highly heterothermic nocturnal organisms with viviparous reproduction [65]. Even though facultative heterothermy may offer an advantage over homeothermic organisms when exploiting alpine environments, this advantage is only applicable to non-reproductive bats. Breeding females cannot decrease their body temperature as much as non-breeding bats due to the metabolic demands of foetal development and lactation [66], so they may be hindered from exploiting high mountain habitats. Consequently, elevational segregation might occur in the coldest regions of their distribution, which would explain the high number of $P$. macrobullaris maternity colonies found below the treeline in the Alps $[41,42]$. Nevertheless, such a pattern was not so noticeable in the slightly milder range of the Pyrenees [19]. Finally, models generated in this study reflect the environmental niche during the favourable season. During winter, palealpine vertebrates behave differently depending on species and taxa: bats hibernate while birds migrate to lower elevations.

\section{Conclusions}

The use of multi-scale modelling allowed us to identify features shaping the biogeographic pattern shared by alpine vertebrates with wide geographic distribution, which could pave the way for future studies and help fine-tune conservation measures for this group of animals. The wide temperature tolerance identified in this study suggests that rather than physiological limitations relating to warmer conditions, ecological factors, such as changes in treeline elevation and the incursion of lowland species, may be the main challenges palealpine species will have to cope with under future conditions resulting from climate change [67]. Palealpine species are found in high-mountain environments not because they are constrained by cold temperatures, but because these cold-tolerant species find in alpine environments their preferred foraging and sheltering habitats, characterized by abundant open-space and rocky areas.

\section{Methods}

\section{Distribution similarity}

We calculated the distribution area overlap of $P$. macrobullaris and 503 European terrestrial vertebrates using the Sørensen Similarity Index (SSI - [68]) in order to identify the species sharing the distribution pattern with $P$. macrobullaris. We generated a reference GIS layer based on updated information about the distribution of $P$. macrobullaris [14] and compared it with breading season distribution layers of 203 mammals available at IUCN Red List [69] and 298 birds obtained from BirdLife International [70]. We also compared the distribution area of $P$. macrobullaris we generated with the area available at IUCN Red List to assess the uncertainty of the data and create a corrected SSI (cSSI) that reflects better the distribution similarities. Visual inspection of the geographical distributions of the species with the highest cSSI values showed that $\mathrm{cSSI}=0.60$ marks a resemblance threshold between widely distributed species limited to mountain ranges and species with a range that extends beyond the main mountain chains.

\section{Environmental Niche Modelling (ENM)}

The extent of the broad-scale models was set as the Western Palearctic region $\left(20-70^{\circ} \mathrm{N},-20-60^{\circ} \mathrm{E}\right)$, while fine-scale models were limited to the Pyrenees and the surrounding area $\left(40-42.1^{\circ} \mathrm{N},-1.1-2.2^{\circ} \mathrm{E}\right)$. All predictive models were generated with the presence-only species distribution modelling software Maxent (Maximum Entropy Algorithm) version 3.3.3 [71,72]. When running the software, we set maximum iterations to 5000, used 10000 background points, and ran 50 replicates of each model, following a resampling method randomly selecting a subsample of $25 \%$ of location records for model validation in each round. The output of all models was set in raw format in order to analyse them using the software ENMTools. Correlation between variables was analysed using ENMTools v1.3 [73], and the variable with a priori the highest ecological meaning was selected when the Spearman's correlation coefficient $(\rho)$ between two variables was greater than 0.65 . The remaining spatial and statistical analyses were performed using ArcView GIS 3.2 and R 2.9.2 software (packages raster and dismo) available from CRAN [74].

\section{Broad-scale modelling}

We used presence location records from all of the known distribution area of P. macrobullaris [14]. In order to minimise errors and ensure the best model performance, we took several measures following Merow et al. [75]. We applied 5 filters to all the available records with the following criteria: (1) Molecular verification: species identification was checked by molecular means to avoid misidentifications with morphologically similar congeners; (2) Resolution: maximum location uncertainty of $1 \mathrm{~km}$; (3) Pseudoreplication: a 
minimum distance of $10 \mathrm{~km}$ between presence records was set based on the home-range information of the species [60,76]; (4) Record source-type homogeneity: similar amount of different record types (e.g. roost observations, net captures); and (5) Geographical homogeneity: similar amount of records in each geographic area. Sampling effort East of the Bosphorus has been considerably lower than in Europe, and the number of European records were four-fold the number of eastern locations after applying the filtering. In order to correct the sampling bias [77], a bias grid was introduced to the algorithm where the relative sampling probability West of the Bosphorus was considered four times higher than the eastern area. This helped outweigh the relative value of Anatolia, the Near East and the Caucasus compared to Europe. Spatial autocorrelation analyses were discarded because the disjunct distribution of alpine species is actually grouped in clusters limited to high mountain massifs.

We modelled the distribution of $P$. macrobullaris at a resolution of 30-arc-second (approximately $1 \mathrm{~km}$ ) using 74 presence records. In order to avoid large unsuitable areas, such as the Siberian steppe or Sahara desert, that could yield artificially inflated model evaluations [78,79], we set a $500 \mathrm{~km}$ buffer around presence locations in the calibration area (Figure 2); i.e. the area from which background points used for generating the model were randomly selected. After filtering highly correlated predictors, we used three types of variables ( 6 climatic, 2 topographic and 1 habitat-related - Table 3) for generating 90 different models (each one including 50 replicates) using different variable combinations and regularization parameters. Climatic variables and elevation data were obtained from WorldClim database [80]. Land Cover data was obtained from GLCNMO [81]. Abruptness of landscape (ABR) was calculated from the elevation grid computing the maximum elevation difference within a $5 \mathrm{~km}$ buffer from each cell. Land cover categories were reclassified to 6 categories: forests, open natural areas, agricultural areas, urban areas, ice/snow and water.

\section{Fine-scale modelling}

We used roost location data for modelling the fine-scale environmental niche of $P$. macrobullaris (Additional file 2: Figure S1). Roosts were identified using the homing-in radio-tracking method [19]. Only roosts located in natural structures were used, as they represent the original as well as the predominant roost type of $P$. macrobullaris [19]. In order to minimise pseudoreplication, one roost for each grid cell was used for the analysis, resulting in a total of 43 records. We used 6 variables (3 topographic and 3 habitatrelated - Table 3) to generate 45 different models. Climatic variables were not used in the fine-scale modelling for being highly correlated with elevation. All variables were edited and homogenised to $100 \mathrm{~m}$ resolution. Elevation data was obtained from CGIAR-CSI [82], and the rest of topographic variables were derived from it. Habitat variables were obtained from Corine Land Cover 2006 [83] and categories were reclassified in ArcView GIS 3.2.

Table 3 Characteristics of the variables used in the two modelling scales

\begin{tabular}{|c|c|c|c|c|}
\hline \multicolumn{5}{|c|}{ Broad-scale modelling } \\
\hline Predictor & Predictor description & Class & Resolution & Source \\
\hline$A B R$ & Abruptness & Topographic & 30 arc-sec & Generated from elevation data \\
\hline ELEV & Elevation & Topographic & 30 arc-sec & Wordclim SRTM \\
\hline B4 & Temperature seasonality & Climatic & 30 arc-sec & Worldclim Bioclim 4 \\
\hline B8 & Mean temperature of the wettest quarter & Climatic & 30 arc-sec & Worldclim Bioclim 8 \\
\hline B10 & Mean temperature of the warmest quarter & Climatic & 30 arc-sec & Worldclim Bioclim 10 \\
\hline B12 & Annual precipitation & Climatic & 30 arc-sec & Worldclim Bioclim 12 \\
\hline B15 & Precipitation seasonality & Climatic & 30 arc-sec & Worldclim Bioclim 15 \\
\hline B17 & Precipitation of the Driest Quarter & Climatic & 30 arc-sec & Worldclim Bioclim 17 \\
\hline LAND & Land cover & Habitat & 30 arc-sec & GLCNMO \\
\hline \multicolumn{5}{|c|}{ Fine-scale modelling } \\
\hline Predictor & Description & Class & Resolution & Source \\
\hline ELEV & Elevation & Topographic & $100 \mathrm{~m}$ & SRTM 90 m DEM (CGIAR-CSI) \\
\hline SLO & Slope & Topographic & $100 \mathrm{~m}$ & Generated from elevation data \\
\hline ORI & Orientation & Topographic & $100 \mathrm{~m}$ & Generated from elevation data \\
\hline DIS-ROCK & Distance to rock areas & Habitat & $100 \mathrm{~m}$ & Obtained from Corine LandCover 2006 \\
\hline DIS-FOREST & Distance to forest areas & Habitat & $100 \mathrm{~m}$ & Obtained from Corine LandCover 2006 \\
\hline DIS-URBAN & Distance to urban areas & Habitat & $100 \mathrm{~m}$ & Obtained from Corine LandCover 2006 \\
\hline
\end{tabular}


Abruptness was used in the broad-scale modelling for reflecting the elevation range available for the bats in each geographic location, and it was based on the homerange information of $P$. macrobullaris $[60,76]$. Conversely, we used slope in the fine-scale modelling because we considered it might play a key role providing suitable rock roosts to $P$. macrobullaris [19].

\section{Model evaluation and selection}

Models were evaluated using both threshold-independent and dependent means that deal with several aspects of model performance, including model accuracy, model complexity and prediction success [84-86]. Accuracy was evaluated using the Area Under the Curve (AUC) of the Receiver Operator Characteristics (ROC) [32,87-90]. Corrected Akaike's Information Criteria (AICc) [91] was used for evaluating model complexity in ENMTools. For that task a single model out of the 50 replicates was selected using a Principal Components Analysis (PCA), in order to identify the replicate with the closest values to the average. The PCA was performed using five matrices: regularised training gain, test gain, test AUC, 10 percentile training presence logistic threshold and 10 percentile training presence area. We also used the threshold-dependent minimal predicted area (MPA) evaluator [92]. Finally, we validated the best broad-scale model using all published distribution records (349) of $P$. macrobullaris [14].

\section{Model output and variable importance}

The best models were repeated and plotted in a logistic format to provide the estimates of the probability of occurrence as predicted by the variables in a map [72,93]. We used the threshold selection method max SSS to discern suitable and unsuitable areas [94]. The relative importance of each variable was checked using heuristic (percent contribution), permutation (permutation importance) and jackknife approaches (Table 2) [95,96]. Response curves for the best explanatory variables were plotted in order to determine the response of suitability values to changes in specific predictors, and thus identify the most suitable conditions for the species (Figure 3).

\section{Additional files}

Additional file 1: Two tables showing the composition, evaluation and variable contribution ranks of the 90 broad-scale models (Table S1) and 45 fine-scale models (Table S2).

Additional file 2: Figure S1. map showing the roosting records used for the fine scale-modelling, Figure $\mathbf{S 2}$. results of the jackknife tests of variable importance of the best broad-scale model, Figure S3. results of the jackknife tests of variable importance of the best fine-scale model, and Figure S4. mean summer temperatures at different elevations and mountain ranges.

\section{Authors' contributions}

$A A$, JA and IG designed the study. All authors participated in the fieldwork. AA performed the analyses. All authors drafted the manuscript. All authors have read and approved the final manuscript.

\section{Acknowledgements}

We wish to thank Orly Razgour for her insightful comments on the manuscript and for proofreading the text. The Basque Government (research projects IT385-07, IT301-10 and IT754-13, and predoctoral grants BFI-2010-190 and BFI-2009-252) and the University of the Basque Country UPV/EHU supported this work.

Received: 5 March 2014 Accepted: 7 October 2014

Published online: 29 October 2014

\section{References}

1. Lomolino MV, Riddle BR, Whittaker RJ, Brown JH: Biogeography. Sunderland: Sinauer Associates; 2010.

2. Hughes PD, Woodward JC, van Calsteren PC, Thomas LE, Adamson KR: Pleistocene ice caps on the coastal mountains of the Adriatic Sea. Quat Sci Rev 2010, 29:3690-3708.

3. Schmitt T, Muster C, Schönswetter P: Are Disjunct Alpine and Arctic-Alpine Animal and Plant Species in the Western Palearctic Really "Relics of a Cold Past?". In Relict Species Phylogeography and Conservation Biology. Edited by Habel JC, Assmann T. Berlin: Springer; 2009:239-252.

4. Ehrich D, Gaudeul M, Assefa A, Koch MA, Mummenhoff K, Nemomissa S, Consortium I, Brochmann C: Genetic consequences of Pleistocene range shifts: contrast between the Arctic, the Alps and the East African mountains. Mol Ecol 2007, 16:2542-2559.

5. Varga ZS, Schmitt T: Types of oreal and oreotundral disjunctions in the western Palearctic. Biol J Linn Soc 2008, 93:415-430.

6. Ozenda P: Die Vegetation Der Alpen Im Europäischen Gebirgsraum. Stuttgart: Fischer; 1988.

7. Roland J, Keyghobadi N, Fownes S: Alpine parnassius butterfly dispersal: effects of landscape and population size. Ecology 2000, 81:1642-1653.

8. Finn DS, Theobald DM, Black WC IV, Poff NL: Spatial population genetic structure and limited dispersal in a Rocky Mountain alpine stream insect. Mol Ecol 2006, 15:3553-3566.

9. Dubuis A, Giovanettina S, Pellissier L, Pottier J, Vittoz P, Guisan A: Improving the prediction of plant species distribution and community composition by adding edaphic to topo-climatic variables. J Veg Sci 2012, 24:593-606.

10. Carranza S, Amat F: Taxonomy, biogeography and evolution of Euproctus (Amphibia: Salamandridae), with the resurrection of the genus Calotriton and the description of a new endemic species from the Iberian Peninsula. Zool J Linnean Soc 2005, 145:555-582.

11. Kryštufek B, BUŽAN EV: Rarity and decline in palaeoendemic Martino's vole Dinaromys bogdanovi. Mammal Rev 2008, 38:267-284.

12. Meffert PJ, Marzluff JM, Dziock F: Unintentional habitats: value of a city for the wheatear (Oenanthe oenanthe). Landscape Urban Plan 2012, 108:49-56.

13. Favaron M, Scherini GC, Preatoni D, Tosi G, Wauters LA: Spacing behaviour and habitat use of rock ptarmigan (Lagopus mutus) at low density in the Italian Alps. J Ornithol 2006, 147:618-628.

14. Alberdi A, Garin I, Aizpurua O, Aihartza J: Review on the geographic and elevational distribution of the mountain long-eared bat Plecotus macrobullaris, completed by utilising a specific mist-netting technique. Acta Chiropterol 2013, 15:451-461.

15. Kiefer $A$, Veith $M$ : A new species of long-eared bat from Europe (Chiroptera: Vespertilionidae). Myotis 2002, 39:5-16.

16. Spitzenberger F, Haring E, Tvrtkovic N: Plecotus microdontus (Mammalia, Vespertilionidae), a new bat species from Austria. Natura Croatica 2002, $11: 1-18$.

17. Spitzenberger F, Strelkov P, Haring E: Morphology and mitochondrial DNA sequences show that Plecotus alpinus Kiefer \& Veith, 2002 and Plecotus microdontus Spitzenberger, 2002 are synonyms of Plecotus macrobullaris Kuzjakin, 1965. Natura Croatica 2003, 12:39-53.

18. Alberdi A, Garin I, Aizpurua O, Aihartza J: The foraging ecology of the mountain long-eared Bat Plecotus macrobullaris revealed with DNA mini-barcodes. PLoS One 2012, 7:e35692. 
19. Alberdi A, Aihartza J, Aizpurua O, Salsamendi E, Brigham M, Garin I: Living above the treeline: roosting ecology of the alpine bat Plecotus macrobullaris. Eur J Wildl Res 2014, doi:10.1007/s10344-014-0862-8.

20. Dietz C, Dietmar N, von Helversen O: Bats of Britain, Europe and Northwest Africa. London: A\&C Black; 2009.

21. Smith SE, Gregory RD, Anderson BJ, Thomas CD: The past, present and potential future distributions of cold-adapted bird species. Divers Distrib 2013, 19:352-362.

22. Bienkowski $P$, Marszalek U: Metabolism and energy budget in the snow vole. Acta Theriol 1974, 19:55-67.

23. Arlott N: Collins Field Guide: Birds of the Palearctic: Passerines. London: Collins; 2007.

24. Boyce M: Scale for resource selection functions. Divers Distrib 2006 12:269-276.

25. Levin SA: The problem of pattern and scale in ecology. Ecology 1992 73:1943-1967.

26. Hortal J, Roura-Pascual N, Sanders NJ, Rahbek C: Understanding (insect) species distributions across spatial scales. Ecography 2010, 33:51-53.

27. Lomba A, Pellissier L, Randin C, Vicente J, Moreira F, Honrado J, Guisan A Overcoming the rare species modelling paradox: a novel hierarchical framework applied to an Iberian endemic plant. Biol Cons 2010, 143:2647-2657.

28. Gaston KJ: The Structure and Dynamics of Geographic Ranges. Oxford: Oxford University Press on Demand; 2003.

29. Pearson RG, Dawson TP, Liu C: Modelling species distributions in Britain: a hierarchical integration of climate and land-cover data. Ecography 2004, 27:285-298

30. Graf RF, Bollmann K, Suter W, Bugmann H: The importance of spatial scale in habitat models: capercaillie in the Swiss Alps. Landscape Ecol 2005 20:703-717

31. Piedallu C, Gégout J-C: Efficient assessment of topographic solar radiation to improve plant distribution models. Agric For Meteorol 2008, 148:1696-1706.

32. Razgour O, Hanmer J, Jones G: Using multi-scale modelling to predict habitat suitability for species of conservation concern: The grey longeared bat as a case study. Biol Cons 2011, 144:2922-2930.

33. Mangerud J, Jakobsson M, Alexanderson H, Astakhov V, Clarke GKC, Henriksen M, Hjort C, Krinner G, Lunkka J-P, Möller P, Murray A, Nikoloskaya $\mathrm{O}$, Saarnisto M, Svendsen II: Ice-dammed lakes and rerouting of the drainage of northern Eurasia during the last glaciation. Quat Sci Rev 2004, 23:1313-1332.

34. Rutishauser MD, Bontadina F, Braunisch V, Ashrafi S, Arlettaz R: The challenge posed by newly discovered cryptic species: disentangling the environmental niches of long-eared bats. Divers Distrib 2012, 18:1107-1119.

35. Hof AR, Jansson R, Nilsson C: The usefulness of elevation as a predictor variable in species distribution modelling. Ecol Model 2012 246:86-90.

36. Hörsch B: Modelling the spatial distribution of montane and subalpine forests in the central Alps using digital elevation models. Ecol Model 2003, 168:267-282.

37. Newbold T, Gilbert F, Zalat S, El-Gabbas A, Reader T: Climate-based models of spatial patterns of species richness in Egypt's butterfly and mammal fauna. J Biogeogr 2009, 36:2085-2095.

38. Yan-Hua Q, Zuo-Hua Y, De Ritis SF: Distribution patterns of snow finches (genus Montifringilla) in the Tibetan Plateau of China. Avocetta 2002, 26:11-18.

39. Saniga M: Seasonal distribution, altitudinal and horizontal migration of the wallcreeper (Tichodroma muraria) in the Malá Fatra Mountais, Slovak Carpathians. Folia Zool 1995, 44:237-246.

40. Luque-Larena JJ, López P, Gosálbez J: Microhabitat use by the snow vole Chionomys nivalis in alpine environments reflects rock-dwelling preferences. Can J Zool 2002, 80:36-41.

41. Mattei-Roesli M: Situazione del genere Plecotus (Chiroptera) nel Cantone Ticino (Svizzera). Boll Soc Ticin Sci Nat 2010, 98:31-34

42. Presetnik P, Koselj K, Zagmajster M: Atlas Netopirjev (Chiroptera) Slovenije. Atlas of Bats (Chiroptera) of Slovenia. Ljubiana: Miklavž na Dravskem polju: Center za kartografijo favne in flore; 2009.

43. Rolando A, Laiolo P. Formica M: A comparative analysis of the foraging behaviour of the Chough Pyrrhocorax pyrrhocorax and the Alpine Chough Pyrrhocorax graculus coexisting in the Alps. Ibis 1997, 139:461-467.
44. Laiolo P, Dondero F, Ciliento E, Rolando A: Consequences of pastoral abandonment for the structure and diversity of the alpine avifauna. J Appl Ecol 2004, 41:294-304

45. Pérez-Aranda D: Biología, ecología, genética y conservación del topillo nival ("Chionomys nivalis") en Peñalara y Sierra Nevada. In PhD Thesis. Madrid: Complutense University, Department of Zoology and Physical Anthropology; 2009

46. Henry PY: Differential migration in the polygynandrous Alpine Accentor Prunella collaris. Bird Study 2011, 58:160-170

47. Laiolo P, Rolando A, Carisio L: Winter movements of the alpine chough: implications for management in the Alps. J Mount Ecol 2001, 6:21-30.

48. McGuire LP, Boyle WA: Altitudinal migration in bats: evidence, patterns, and drivers. Biol Rev 2013, 88:767-786.

49. Bech N, Boissier J, Drovetski S, Novoa C: Population genetic structure of rock ptarmigan in the "sky islands" of French Pyrenees: implications for conservation. Anim Conserv 2009, 12:138-146.

50. Janeau G, Aulagnier S: Snow vole - Chionomys nivalis. Ibex JME 1997, $4: 1-11$.

51. Janiga M, Novotná M: Feeding preferences and foraging behaviour in the Alpine Accentor Prunella collaris. Ornis Fennica 2006, 83:170-180

52. Ninot JM, Carrillo E, Font X, Carreras J, Ferré A, Masalles RM, Soriano I, Vigo $\mathrm{J}$ : Altitude zonation in the Pyrenees. A geobotanic interpretation. Phytocoenologia 2007, 37:371-398.

53. Beck J, Altermatt F, Hagmann R, Lang S: Seasonality in the altitude-diversity pattern of Alpine moths. Basic Appl Ecol 2010, 11:714-722

54. Barry RG: Mountain Weather and Climate. 3rd edition. New York: Cambridge University Press; 2008.

55. Araújo MB, Luoto M: The importance of biotic interactions for modelling species distributions under climate change. Global Ecol Biogeogr 2007, 16:743-753.

56. Wisz MS, Pottier J, Kissling WD, Pellissier L, Lenoir J, Damgaard CF, Dormann CF, Forchhammer MC, Grytnes J-A, Guisan A, Heikkinen RK, Høye TT, Kühn I, Luoto M, Maiorano L, Nilsson M-C, Normand S, Öckinger E, Schmidt NM, Termansen M, Timmermann A, Wardle DA, Aastrup P, Svenning J-C: The role of biotic interactions in shaping distributions and realised assemblages of species: implications for species distribution modelling. Biol Rev 2012, 88:15-30.

57. de Araújo CB, Marcondes-Machado LO, Costa GC: The importance of biotic interactions in species distribution models: a test of the Eltonian noise hypothesis using parrots. J Biogeogr 2013, 41:513-523.

58. Dietrich S, Szameitat DP, Kiefer A, Schnitzler HU, Denzinger A: Echolocation signals of the plecotine bat, Plecotus macrobullaris Kuzyakin, 1965. Acta Chiropterol 2006, 8:465-475.

59. Razgour O, Clare EL, Zeale M, Hanmer J, Schnell I, Rasmussen M, Gllbert T, Jones $\mathrm{H}$ : High-throughput sequencing offers insight into mechanisms of resource partitioning in cryptic bat species. Ecol Evol 2011, 1(4):556-570.

60. Arthur L, Lemaire M: Les Chauves-Souris De France, Belgique, Luxembourg Et Suisse. Meze: Biotope Editions; 2009.

61. Tvrtkovic N, Pavlinic I, Haring E: Four species of long-eared bats (Plecotus, Geoffroy, 1818; Mammalia, Vespertilionidae) in Croatia: field identification and distribution. Folia Zool 2005, 54:75-88.

62. Pavlinic I, Tyrtkovic N: Altitudinal distribution of four Plecotus species (Mammalia, Vespertilionidae) occurring in Croatia. Croatian Natural History Museum 2004, 13:395-401.

63. Gaston KJ: Rarity (Population and Community Biology Series). 1st edition. Falmouth, UK: Springer; 1994

64. Bicudo JE, Buttemer WA, Chappell MA, Pearson JT, Bech C: Ecological and Environmental Physiology of Birds. New York: Oxford University Press; 2010.

65. Kunz TH, Fenton MB: Bat Ecology. Chicago: University of Chicago Press; 2006.

66. Dzal YA, Brigham RM: The tradeoff between torpor use and reproduction in little brown bats (Myotis lucifugus). J Comp Physiol B 2012, 183:279-288.

67. Reif J, Flousek J: The role of species ecological traits in climatically driven altitudinal range shifts of central European birds. Oikos 2012, 121:1053-1060.

68. Sørensen T: A method of establishing groups of equal amplitude in plant sociology based on similarity of species and its application to analyses of the vegetation on Danish commons. Biol Skr 1948, 5:1-34.

69. IUCN Red List of Threatened Species. [http://www.iucnredlist.org]

70. BirdLife International. [http://www.birdlife.org]

71. Phillips SJ, Anderson RP, Schapire RE: Maximum entropy modeling of species geographic distributions. Ecol Model 2006, 190:231-259. 
72. Phillips S, Dudík M: Modeling of species distributions with Maxent: new extensions and a comprehensive evaluation. Ecography 2008, 31:161-175.

73. Warren D, Glor R, Turelli M: ENMTools: a toolbox for comparative studies of environmental niche models. Ecography 2010, 33:607-611.

74. The Comprehensive R Archive Network. [http://cran.r-project.org/]

75. Merow C, Smith MJ, Silander JA Jr: A practical guide to MaxEnt for modeling species' distributions: what it does, and why inputs and settings matter. Ecography 2013, 36:1058-1069.

76. Preatoni D, Spada M, Wauters L, Tosi G, Martinoli A: Habitat use in the female Alpine long-eared bat (Plecotus macrobullaris): does breeding make the difference? Acta Chiropterol 2011, 13:355-364.

77. Kramer-Schadt S, Niedballa J, Pilgrim JD, Schröder B, Lindenborn J, Reinfelder V, Stillfried M, Heckmann I, Scharf AK, Augeri DM, Cheyne SM, Hearn AJ, Ross J, Macdonald DW, Mathai J, Eaton J, Marshall AJ, Semiadi G, Rustam R, Bernard H, Alfred R, Samejima H, Duckworth JW, Breitenmoser-Wuersten C, Belant JL, Hofer $H$, Wilting A: The importance of correcting for sampling bias in MaxEnt species distribution models. Divers Distrib 2013, 19:1366-1379.

78. Lobo JM, Jiménez-Valverde A, Real R: AUC: a misleading measure of the performance of predictive distributingon models. Global Ecol Biogeogr 2008, 17:145-151.

79. VanDerWal J, Shoo L, Graham CH, Williams S: Selecting pseudo-absence data for presence-only distribution modeling: How far should you stray from what you know? Ecol Model 2009, 220:589-594.

80. Hijmans $\mathrm{R}$, Graham $\mathrm{CH}$ : The ability of climate envelope models to predict the effect of climate change on species distributions. Glob Chang Biol 2006, 12:1-10.

81. Global Land Cover by National Mapping Organizations (GLCNMO). [http://www.iscgm.org/]

82. Consortium for spatial information (CGIAR-CSI). [http://www.cgiar-CSi.org]

83. Corine Land Cover 2006. [http://sia.eionet.europa.eu/CLC2006]

84. Murphy AH, Winkler RL: A general framework for forecast verification. Mon Weather Rev 1987, 115:1330-1338.

85. Pearce J, Ferrier S: Evaluating the predictive performance of habitat models developed using logistic regression. Ecol Model 2000, 133:225-245.

86. Warren D, Seifert S: Ecological niche modeling in Maxent: the importance of model complexity and the performance of model selection criteria. Ecol Appl 2011, 21:335-342.

87. Rebelo H, Jones $\mathrm{G}$ : Ground validation of presence-only modelling with rare species: a case study on barbastelles Barbastella barbastellus (Chiroptera: Vespertilionidae). J Appl Ecol 2010, 47:410-420.

88. Boubli J, de Lima M: Modeling the geographical distribution and fundamental niches of Cacajao spp. And Chiropotes israelita in Northwestern Amazonia via a maximum entropy algorithm. Int J Primatol 2009, 30:217-228.

89. Wisz M, Hijmans R, Li J, Peterson A, Graham C, Guisan A: Effects of sample size on the performance of species distribution models. Divers Distrib 2008, 14:763-773.

90. Giovanelli J, De SM, Haddad C, Alexandrino J: Modeling a spatially restricted distribution in the Neotropics: How the size of calibration area affects the performance of five presence-only methods. Ecol Model 2010, 221:215-224.

91. Burnham KP, Anderson DR: Model Selection and Multi-Model Inference. 2nd edition. Berlin: Springer; 2002

92. Engler R, Guisan A, Rechsteiner L: An improved approach for predicting the distribution of rare and endangered species from occurrence and pseudo-absence data. J Appl Ecol 2004, 41:263-274.

93. Elith J, Phillips SJ, Hastie T, Dudík M, Chee YE, Yates CJ: A statistical explanation of MaxEnt for ecologists. Divers Distrib 2010, 17:43-57.

94. Liu C, White M, Newell G: Selecting thresholds for the prediction of species occurrence with presence-only data. J Biogeogr 2013, 40:778-789.

95. Yost AC, Petersen SL, Gregg M, Miller R: Predictive modeling and mapping sage grouse (Centrocercus urophasianus) nesting habitat using Maximum Entropy and a long-term dataset from Southern Oregon. Ecol Inform 2008, 3:375-386.

96. Moratelli R, Andreazzi CS D, de Oliveira JA, Cordeiro J: Current and potential distribution of Myotis simus (Chiroptera, Vespertilionidae). Mammalia 2011, 75:227-234

\section{doi:10.1186/s12983-014-0077-6}

Cite this article as: Alberdi et al:: Unveiling the factors shaping the distribution of widely distributed alpine vertebrates, using multi-scale ecological niche modelling of the bat Plecotus macrobullaris. Frontiers in Zoology 2014 11:77.

\section{Submit your next manuscript to BioMed Central and take full advantage of:}

- Convenient online submission

- Thorough peer review

- No space constraints or color figure charges

- Immediate publication on acceptance

- Inclusion in PubMed, CAS, Scopus and Google Scholar

- Research which is freely available for redistribution 